INTER NATIONAL MONETARY FUND

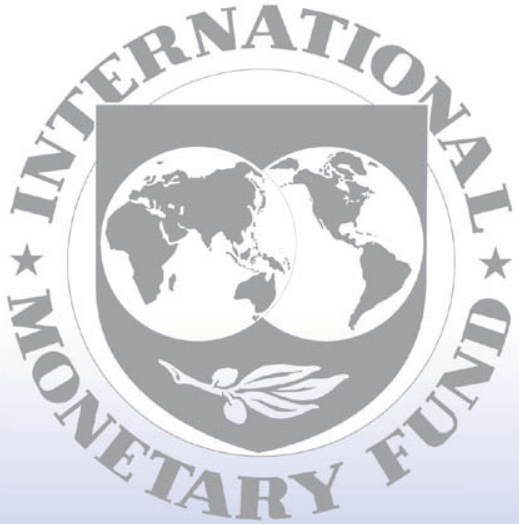

Staff

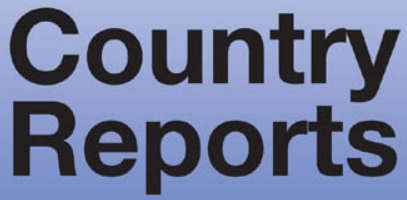




\section{United States: Publication of Financial Sector Assessment Program Documentation- Technical Note on Selected Issues on Liquidity Risk Management in Fedwire Funds and Private Sector Payment}

This Technical Note on Selected Issues on Liquidity Risk Management in Fedwire Funds and Private Sector Payment for the United States was prepared by a staff team of the International Monetary Fund. It is based on the information available at the time it was completed in May 7, 2010. The views expressed in this document are those of the staff team and do not necessarily reflect the views of the government of the United States or the Executive Board of the IMF.

Copies of this report are available to the public from

International Monetary Fund $\bullet$ Publication Services

700 19th Street, N.W. • Washington, D.C. 20431

Telephone: (202) 6237430 • Telefax: (202) 6237201

E-mail: publications@imf.org • Internet: http://www.imf.org

\section{International Monetary Fund Washington, D.C.}


FinANCIAL SECTOR ASSESSMENT PROGRAM

\section{UNITED STATES OF AMERICA}

SELECTED ISSUES ON LIQUIDITY RISK MANAGEMENT IN FEDWIRE Funds AND PRIVATE SECTOR PAYMENT Systems

TECHNICAL NOTE

MAY 2010

INTERNATIONAL MONETARY FUND

MONETARY AND CAPITAL MARKETS DEPARTMENT 
4053526

CInternational Monetary Fund. Not for Redistribution 
Glossary

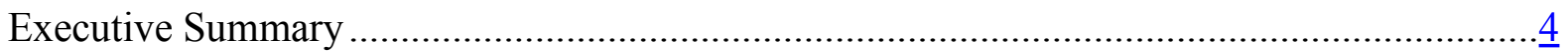

I. Overview

II. Central Bank Policy in Providing Liquidity to Payment Systems and Critical Market Infrastructures....

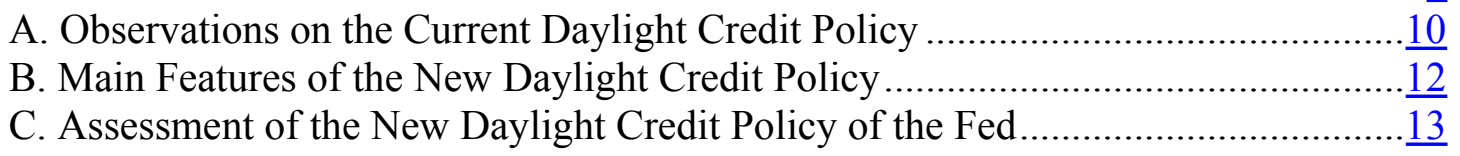

III. Efforts to Reduce Late-Day Settlement in Payment Systems and Market Infrastructures.

A. Liquidity Saving Mechanism in Fedwire Funds .............................................14

B. Reducing End-of-Day Settlement in CHIPS .....................................................

IV. Risk Management

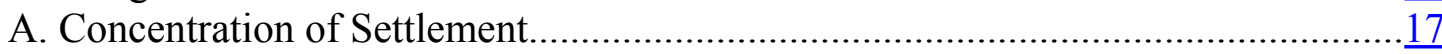

B. Stress Testing and Simulations ...........................................................................

C. Operational Resilience ................................................................................

D. Access of Systemically Important Infrastructures to Central Bank Services ….......20

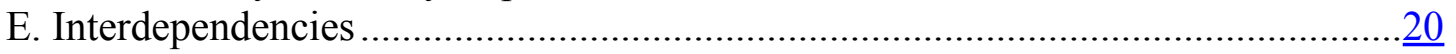

Tables

1. Overview of the Large Value Payment Systems Operating in the United States ................... 1

2. Comparison of Intraday Credit Policies Between the U.S. and Selected Countries..............10

3. Key Elements of the Current and Revised PSR Policy for Daylight Credit.........................

Box

1. Overview of the CHIPS Settlement Model...... 


\section{GLOSSARY}

CHIPS

CLS

CMS

CPSIPS

CPSS

DTC

EPN

FBOs

Fed

FICC

FX

IOSCO

MCA

PRC

PSR

RTGS

SSS

WCAG
Clearing House Interbank Payments System

Continuous Linked Settlement

Collateral Management System

CPSS Core Principles for Systemically Important Payment Systems

Committee on Payment and Settlement Systems

Depository Trust Company

Electronic Payments Network

Foreign Banking Organizations

Federal Reserve

Fixed Income Clearing Corporation

Foreign Exchange

International Organization of Securities Commissions

Monetary Control Act

Payment Risk Committee

Payment System Risk

Real Time Gross Settlement System

Securities Settlement System

Wholesale Customer Advisory Group 


\section{EXECUTIVE SUMMARY ${ }^{1}$}

The U.S. payment and settlement systems continued to function smoothly during the 2007-2008 period of market stress. This owed both to the robustness of the systems' risk management and infrastructure and to the actions by the Federal Reserve (Fed) to sharply increase balances held at the Federal Reserve Banks by financial institutions (reserve balances).

\section{However, especially as the Fed's extraordinary liquidity support is withdrawn, underlying vulnerabilities within the system will need to be addressed, most notably:}

- Intraday credit from the Fed is largely in the form of uncollateralized but capped daylight overdrafts (where uncollateralized intraday overdraft caps are generally set as a percentage of the capital of the financial institution), subject to an administered fee. Caps and fees encourage some large depository institutions to delay settlement of large-value funds payments over Fedwire Funds (the Fed's Real Time Gross Settlement (RTGS) system) until late in the day, especially for fees avoidance purposes.

- The fact that the Fedwire Funds system provides neither a central queuing/payment offsetting mechanism nor other liquidity saving features exacerbates the problem of late payments in Fedwire Funds. ${ }^{2}$

These issues pose risks both domestically and internationally. Domestically, the increase in late-in-the-day payments leaves the payment system as a whole more vulnerable in case of a late-in-the-day operational disruption. Internationally, the end-of-day closure of U.S. payment systems effectively means the worldwide "end-of day" so a liquidity disruption in the U.S. system could constitute a critical shock that could propagate systemic risk at the following day opening in Asia and Europe.

The new intraday liquidity policy of the Fed, to be implemented late 2010 or early 2011, will help address some of the risks presently facing the payment system. The new Payment System Risk (PSR) policy promotes the collateralization of intraday credit. Collateralized overdrafts under the new policy will not be charged a fee and will therefore work both to reduce the incentive to delay certain payments until late in the day, as well as to reduce the Fed's credit risk from providing intraday credit. Although substantial, the effectiveness of these changes (and others underway) in encouraging Fedwire participants to send payments earlier in the day will need to be assessed over the medium term, and it remains to be seen whether additional steps to amend the intraday credit framework (e.g., relaxing further or removing net debit caps) would also help.

\footnotetext{
${ }^{1}$ This Technical Note was prepared by Frédéric Hervo (external expert, Banque de France).

${ }^{2}$ Some of this functionality is, however, provided by CHIPS, a private-sector funds transfer system.
} 
While an asymmetric treatment of foreign banking organizations (FBOs) exists regarding the calculation of the capital measure for caps and the fee deductible, policy provisions implemented in March 2009 substantially addressed this asymmetry. For example, highly-rated FBOs are eligible for a fee deductible based on 100 percent of worldwide capital, the same capital measure used for U.S. chartered institutions, and highlyrated FBOs are eligible for additional collateralized capacity under a streamlined process. Additionally, under the new policy, the fee deductible is eliminated for all institutionsFBOs and U.S. chartered institutions. While these changes represent substantial progress toward the equitable treatment of FBOs, additional steps could be considered to provide a more level playing field relative to U.S. banks while ensuring an adequate level of comfort with respect to credit risk mitigation.

\section{Steps are needed to amend Fedwire's settlement procedures for tri-party repo} transactions, Depository Trust Company (DTC), and Clearing House Interbank Payments System (CHIPS) to discourage late-in the-day payments. The Fed identified a four-prong approach, including revising the PSR policy, exploring the introduction of a liquidity saving mechanism for Fedwire Funds, and making liquidity improvements for CHIPS and DTC, to move payments earlier in the day. ${ }^{3}$ The CHIPS system has been successful in reducing the amount of payments processed late, especially by encouraging its participants voluntarily to provide supplemental funding earlier. However, further efforts in this area should be encouraged especially since the underlying risks may re-emerge as liquidity levels return to normal.

\section{ONGOING EFFORTS AND RECOMMENDATIONS}

\section{Ongoing efforts}

- Over the past several years, the Fed has outlined steps to improve the payment system, including the following:

- Implement and take further steps, as appropriate, to increase collateralized intraday credit and reduce uncollateralized overdrafts as a way to (i) strengthen the credit risk management of the Reserve Banks, (ii) incentivize institutions to send large-value funds payments earlier in the day, and (iii) further align the treatment of FBOs and U.S. chartered banks.

- Explore the introduction of liquidity-saving features in Fedwire Funds.

- Support the continued efforts by the private sector to reduce late-in-the-day settlements associated primarily with tri-party repo and settlement processes in DTC and CHIPS.

\footnotetext{
${ }^{3} 73$ FR 79110, December 24, 2008.
} 


\section{Recommendations}

- In line with the Administration's proposal, the Fed Banks should be granted the legal right to give access to accounts and liquidity to systemically important post-trade market infrastructures as an additional buffer to mitigate systemic risk.

- The Fed, in cooperation with other relevant agencies, should continue to review the ability of payment, clearing, and settlement systems to cope with extreme liquidity stress scenarios in light of the lessons of the crisis, on the basis of stress testing scenarios and simulations, taking into account the concentration of payment and settlement services, as well as the complex interdependencies among systems. 


\section{OVERVIEW}

1. The U.S. wholesale payment infrastructure comprises two systems, which are of a systemic importance and settle in central bank money. The Fed Banks' Fedwire Funds Services (Fedwire) is a real time gross settlement system (RTGS) operated by the Fed, while the Clearing House Interbank Payments System (CHIPS) is a private sector system combining net and gross real time settlement. In addition to these domestic systems, payments services are offered by Continuous Linked Settlement Bank International (CLS Bank), which operates payment versus payment settlement services in 17 currencies mainly for foreign exchange (FX) related transactions. ${ }^{4}$

\section{Table 1. Overview of the Large Value Payment Systems Operating in the United States}

\begin{tabular}{|c|c|c|c|c|c|}
\hline System & $\begin{array}{c}\text { Average daily } \\
\text { value } \\
\text { (Q2 2009- } \\
\text { USD trillion) }\end{array}$ & $\begin{array}{c}\text { Percentage } \\
\text { change from } \\
\text { one year ago }\end{array}$ & $\begin{array}{c}\text { Average daily } \\
\text { volume } \\
\text { (Q2 2009- } \\
\text { thousands) }\end{array}$ & $\begin{array}{c}\text { Percentage } \\
\text { change from } \\
\text { one year ago }\end{array}$ & $\begin{array}{c}\text { Number of } \\
\text { direct } \\
\text { participants }\end{array}$ \\
\hline $\begin{array}{c}\text { Fedwire } \\
\text { Funds }\end{array}$ & 2.49 & -15.8 & 498 & -5.6 & 7,300 \\
\hline CHIPS & 1.43 & -33.2 & 330 & -9.7 & 48 \\
\hline CLS* & 3.34 & -20.6 & 590 & +15.9 & 59 \\
\hline
\end{tabular}

*CLS data excludes Memorial Day, a U.S. dollar holiday.

2. In contrast, the U.S. retail payment infrastructure is more fragmented. There are two national Automated Clearing House operators: the Reserve Banks and Electronic Payments Network (EPN, a private sector entity) and several regional and interregional check image exchanges and card payment schemes.

3. The U.S. wholesale payment infrastructure is at the heart of a complex network of critical interdependencies, both from domestic and international perspectives. The most significant example is CLS Bank, which is linked for funding purposes to the RTGS systems of the 17 central banks for the currencies currently eligible in the system.

\section{U.S. payment and settlement systems were a source of strength throughout the} 2007-2008 period of market stress. The systems performed well, including the implementation of participant failure management procedures, despite the significant challenges arising from unprecedented financial market stresses, higher than normal and more variable payment and settlement volumes and values, the financial difficulties of a number of

\footnotetext{
${ }^{4}$ Although this report covers issues related to CLS, a full review of CLS risk management is beyond its scope.
} 
individual financial institutions, and a higher degree of uncertainty regarding counterparty risk. Despite these challenges, the U.S. systems were able to complete settlement on the day of value.

5. The settlement and operational risk management frameworks for the U.S. payment systems appear to be robust. A formal assessment of the compliance of the various systems with international standards, namely the Committee on Payment and Settlement System (CPSS) Core Principles for Systemically Important Payment Systems (CPSIPS), was not performed. Self-assessments of Fedwire Funds, CHIPS and CLS Bank, conducted prior to the mission, suggested a full compliance of the three systems with CPSIPS. $^{5}$

6. During the turmoil, the Fed, the Securities and Exchange Commission, the Commodity Futures Trading Commission, the Treasury Department and other regulators undertook significant action to help ensure the smooth functioning of the financial markets, including the payments system. These included massive liquidity injections to help address the dislocation of the interbank market from September 2008 onwards, as well as obtaining Congressional approval for an accelerated implementation of payment of interest on reserves. As a result, reserve balances rose from an average of around US $\$ 9$ billion in early 2008 to over US\$1 trillion in October 2009. This increase in reserve balances did not prevent, however, a temporary increase in the demand for intraday credit during the crisis, likely reflecting among other factors an increase in values transferred over the Fedwire Funds and Securities services, and risk aversion. For instance, during the period which followed the collapse of Lehman Brothers (between September 15 and October 24, 2008) the use of daylight overdrafts by Fedwire Funds participants increased about 50 percent compared to the previous quarter.

7. In recent decades, the increased use of gross settlement and real time finality in payment systems have mitigated or even eliminated a large part of settlement risk but have created additional structural demand for intraday credit. The emergence of some categories of time-critical payments as a risk management tool for some systems (e.g., CLS Bank funding requirements) that have to be completed within tight intraday deadlines have also increased intraday liquidity pressures.

\section{Increased demand for intraday credit, which has been observed in most} industrial countries, is exacerbated by specific features in the United States. Starting in the late 1980s, financial institutions began decreasing their overnight reserve balances. More recently, late-in-the-day payments associated with the settlement of tri-party repo grew, and settlement procedures in CHIPS and DTC tended to lock up significant amounts of liquidity until late in the day.

\footnotetext{
${ }^{5}$ See http://www.treas.gov/offices/international-affairs/standards/standards.shtml.
} 


\section{Central Bank Policy in Providing Liquidity to Payment Systems AND CRITICAL MARKET INFRASTRUCTURES}

\section{Since the 1980s, the Fed was explicit in its desire to limit its provision of intraday} credit, reflecting a desire to insulate the Fed System from credit risk. As a result, while daylight overdrafts are uncollateralized, access is capped and subject to a fee. ${ }^{6}$ Collateral is typically required for overdrafts above the net debit cap (but still subject to a maximum cap). ${ }^{7}$ The control over the level of intraday credit provided and fees are the main tools used by the Fed to minimize the use of daylight overdrafts by participants. ${ }^{8}$ This differs from most central banks in other major financial centers, where the practice is typically to provide collateralized intraday credit without a fee or cap.

\section{In 2008, the Board of the Governors approved a revision to its PSR policy that permits and encourages the collateralization of intraday credit for all depository} institutions. Provisions significantly improving the equity of the policy's treatment of FBOs went into effect in March 2009, and the remaining provisions of the new policy will go into effect upon the implementation of the full policy in late 2010 or early 2011 . These changes build on a review process and formal public consultation that was initiated in 2001 (the proposals are discussed below). In the revised PSR policy, the Board maintains its policy objectives of balancing safety and efficiency and explicitly recognizes the role of the central bank in providing intraday credit to healthy depository institutions. ${ }^{9}$

\footnotetext{
${ }^{6}$ The net debit cap is based on a multiple of the capital measure of the institution that is linked to an assessment of creditworthiness. The cap can be increased based on business need and the institution's risk characteristics.

${ }^{7}$ Overnight loans from the discount window facility of the Federal Reserve are, however, fully collateralized, and potential borrowers establish standing pools of collateral to cover these loans. The Federal Reserve has a general lien upon any unencumbered discount window collateral to cover a failure to extinguish an uncollateralized daylight overdraft.
}

${ }^{8}$ During the public consultation on revisions to the PSR policy in 2008, the Board shifted its approach from treating intraday credit as inherently undesirable to acknowledging the role of the central bank in providing intraday credit to healthy depository institutions: "In the past, the Board also had concerns that accepting collateral to address Reserve Bank credit risk for daylight overdrafts would not provide strong incentives to reduce the level of intraday credit. In particular, there was concern that because of the wide range of collateral accepted by the Reserve Banks, depository institutions would have weak incentives to reduce their use of intraday credit. Under the new strategy, the purpose of Reserve Banks accepting collateral is not to control the level of overdrafts per se, but to mitigate credit risk to the Reserve Banks when they provide intraday balances and credit needed for the smooth operation of the payments system." The revisions will be implemented in late 2010 or early 2011, but until the revisions take effect, the policy continues to state that "the Board expects depository institutions to manage their Federal Reserve accounts effectively and minimize their use of Federal Reserve daylight credit."

973 FR 79109, December 24, 2008. 
Table 2. Comparison of Intraday Credit Policies between the U.S. and Selected Countries

\begin{tabular}{|l|l|c|c|}
\hline & \multicolumn{1}{|c|}{ Use of Collateral } & $\begin{array}{c}\text { Maximum } \\
\text { Amount/cap }\end{array}$ & Fee/Interest \\
\hline Canada & Collateralized (pledge) & No & Free \\
\hline Eurosystem & Collateralized (pledge/repo) & No & Free \\
\hline Japan & Collateralized & No & Free \\
\hline United Kingdom & Collateralized (repo) & No $^{10}$ & Free \\
\hline $\begin{array}{l}\text { United States } \\
\text { (current policy) }\end{array}$ & $\begin{array}{l}\text { Only for problem institutions and } \\
\text { institutions with maximum caps }\end{array}$ & Yes & Yes \\
\hline
\end{tabular}

\section{A. Observations on the Current Daylight Credit Policy}

\section{Many large depository institutions defer until late in the day sending a} significant number of large-value funds transfers due to a number of market factors and to avoid daylight overdraft fees. The Fedwire Funds system does not provide a queuing/payment offsetting mechanism to its participants, making the completing of payments in the RTGS payment system highly dependent upon the availability of a sufficient daylight overdraft capacity or balances. Although Fedwire Funds has one of the widest operating hours among major RTGS payment systems (i.e., the operating day of Fedwire Funds for the value date D starts on D-1 at 9:00 p.m. ET and closes at 6:30 p.m. on D), more than 60 percent of payment value in 2008 was settled after 3:30 p.m., more than 40 percent after 4:30 p.m. and more than 30 percent after 5:00 p.m. The share of the value of payments sent after 5:00 p.m. grew by 10 percentage points between 1998 and 2007, driven largely by the largest payments, including the funds transfers used to complete the daily cycle of financial market settlement payments. Late-day payments are related to a number of factors, including efforts to avoid fees on daylight overdrafts from the Fed. These late-day payments raise potential systemic concerns, given the uncertainty this leaves with regard to completion of large and critical payments at value date.

\section{An additional concern is that access of depository institutions to uncollateralized} daylight overdrafts leaves the Fed subject to credit risk. However, the Fed has a robust program in place to mitigate the risks posed by extending daylight overdrafts and no credit losses have been experienced to date. ${ }^{11}$ The Fed's exposure to daylight overdrafts has

\footnotetext{
${ }^{10}$ However, if more than $£ 1$ billion is to be borrowed, the borrowing institution must ensure that the securities of any single issuer (other than the U.K. government and the Bank of England) comprise no more than 25 percent of the total collateral it has repoed to the Bank.

${ }^{11}$ The Reserve Banks monitor the financial condition of institutions to ensure they meet the safety and soundness requirements to access intraday credit. Monitoring tools include, but are not limited to, supervisory information, analytical reporting, and predictive models. Net debit caps establish limits on the amount of
} 
decreased in 2009, owing to the increase in reserve balances held by banks. In 2007 the average daily overdraft of the banking system as a whole was approximately US $\$ 60$ billion and the average daily peak overdraft US $\$ 160$ billion. In 2009, the average and peak daylight overdrafts stood at US\$10 and US\$55 billion, respectively. ${ }^{12}$ While demand for daylight overdrafts is not expected to remain at 2009 levels, the future demand for daylight overdrafts is unclear for a number of reasons, including the level of balances that banks will hold as banking conditions normalize, as well as changes resulting from the revised PSR policy.

\section{The Fed's daylight credit policy has also imposed administrative and technical}

costs. The largest users of intraday credit (representing less than 3 percent of institutions with intraday credit but comprising the most active players in Fedwire Funds) must undertake a comprehensive self-assessment of their creditworthiness in order to justify their net debit cap (see "Guide to the Fed's Payment System Risk Policy on Daylight Credit"). In addition, participants are subject to fees on daylight overdrafts, which stood at US $\$ 32.2$ million in 2003, peaked at US\$65 million in 2007, and dropped to US\$5 million in 2009. Therefore, some participants, primarily a handful of the largest users, have built systems to manage internal queues of payments and monitor intraday liquidity usage, in order to minimize fees paid on the use of their daylight overdraft capacity.

\section{The existing daylight credit policy also does not ensure a completely level playing} field between domestic-chartered institutions and foreign participants in their use of Fedwire. Until March 2009, the capital used in determining the net debit cap for FBOs was limited to 35 percent of the capital of the parent company of the U.S. branch or subsidiary of the FBO (instead of 100 percent of the capital for U.S. domestic institution), even for the most-highly rated ones. ${ }^{13}$ In 2007, FBOs as a group incurred average peak overdrafts that were less than 50 percent of their single day capacity. Although FBOs are generally unconstrained by their caps, some FBOs may have approached their limits on certain liquidity intensive payment days, before the crisis. This lower cap also reduces the so-called "deductible" amounts, i.e., a waiver reducing the fee applied to the daylight overdraft, since it is calculated with reference to a capital measure. During the mission, some anecdotal evidence was provided by private sector participants suggesting that some FBOs limit or refrain from self-clearing in the payment system and channel their payment flows to U.S. chartered banks, or delay non-time-critical payments as late in the day as possible. In March 2009, the most creditworthy FBOs were granted a streamlined process for receiving additional collateralized capacity up to the value of their net debit cap calculated on 100 percent of their capital. Additionally, these FBOs were granted a fee deductible based on

intraday credit to any institution. Finally, institutions that pose elevated credit risk are placed on a "watch list" for more frequent monitoring and additional targeted risk mitigation steps, as appropriate.

${ }^{12}$ Source for daylight overdraft data: http://www.federalreserve.gov/paymentsystems/psr_dlod.htm.

${ }^{13}$ In countries where the provision of intraday credit is unlimited but fully collateralized, foreign participants are usually treated like domestic participants. 
100 percent of capital. The reasons stated in the PSR policy for the differential treatment are the greater difficulty in assessing the creditworthiness of FBO and the greater risk that may be implied by foreign insolvency laws. However, alternative tools may be considered, including a jurisdiction-by-jurisdiction analysis of the materiality of these risks, which may at the same time provide for adequate risk containment without raising the same levelplaying field concerns as a blanket penalty.

\section{B. Main Features of the Future Daylight Credit Policy}

\section{The Fed's new strategy would explicitly encourage the use of collateral to} contain credit risk in providing daylight overdrafts. Collateralized daylight overdrafts would be charged a zero fee, and to encourage collateralized borrowing, the fee for uncollateralized daylight overdrafts would be increased to 50 basis points (annual rate) from the current 36 basis points. In addition, the two-week average net debit cap would be eliminated, while retaining the higher single-day cap for healthy depository institutions, which would effectively raise caps by approximately 50 percent. Access to daylight credit would continue to be available only to institutions with regular access to the discount window, with the same collateral eligibility criteria and haircuts used for both overnight and intraday credit. Unencumbered collateral pledged for discount window purposes could be used to support intraday credit.

\section{Table 3. Key Elements of the Current and Revised PSR policy for Daylight Credit}

\begin{tabular}{|c|c|c|}
\hline Main patterns & Current policy & Revised policy \\
\hline Collateral & $\begin{array}{l}\text { Required for problem institutions } \\
\text { and institutions with max caps }\end{array}$ & $\begin{array}{l}\text { Pledging collateral will be explicitly } \\
\text { encouraged through a more } \\
\text { favorable pricing of collateralized } \\
\text { daylight overdrafts }\end{array}$ \\
\hline $\begin{array}{l}\text { Fee for collateralized daylight } \\
\text { overdrafts }\end{array}$ & 36 basis points & Zero fee \\
\hline $\begin{array}{l}\text { Fee for uncollateralized } \\
\text { daylight overdrafts }\end{array}$ & 36 basis points & 50 basis points \\
\hline $\begin{array}{l}\text { Deductible amount (subtracted } \\
\text { from fees levied on daylight } \\
\text { overdrafts) }\end{array}$ & $\begin{array}{l}10 \text { percent of an institution's } \\
\text { capital measure }\end{array}$ & $\begin{array}{l}\text { Replaced by zero fee for } \\
\text { collateralized daylight overdrafts } \\
\text { and fee waiver }\end{array}$ \\
\hline Fee waiver & Up to US\$25 biweekly & US $\$ 150$ biweekly \\
\hline Net debit cap & $\begin{array}{l}\text { Two-week average limit and } \\
\text { higher single-day limit. Ex-post } \\
\text { counseling if exceed limit }\end{array}$ & $\begin{array}{l}\text { Two-week average limit } \\
\text { eliminated; single-day limit } \\
\text { retained. Flexibility in ex post } \\
\text { counseling if fully collateralized }\end{array}$ \\
\hline Max cap & $\begin{array}{l}\text { Additional collateralized capacity } \\
\text { above net debit cap for self- } \\
\text { assessed institutions }\end{array}$ & $\begin{array}{l}\text { Streamlined process for certain } \\
\text { FBOs up to a limit (effective } \\
\text { March } 26,2009 \text { ). Minor changes } \\
\text { apply for all institutions }\end{array}$ \\
\hline $\begin{array}{l}\text { Penalty fee for ineligible } \\
\text { institutions }\end{array}$ & $136 \mathrm{bps}$ & $150 \mathrm{bps}$ \\
\hline
\end{tabular}

Source: Notice of the Federal Reserve Board of Governors of December 24, 2008 on the revised PSR Policy. 


\section{Comments on the Future Daylight Credit Policy}

\section{Experience will determine whether the new policy sufficiently encourages} participants to move to voluntary collateralized daylight credit and reduce late-in-theday payments. The higher fee for uncollateralized overdrafts would need to be compared with the opportunity costs of delivering collateral. Because the range of collateral accepted by the Fed is very broad relative to other liquidity sources, the opportunity cost of pledging new collateral will likely not be significant. ${ }^{14}$ As of end 2009, US\$1.2 trillion in assets were pledged with the Reserve Banks mainly for discount window purposes, most of which was unencumbered by loans, with no real opportunity cost. Less than 60 percent of mid-to-large users have collateral pledged for discount window purposes (less than 50 percent of total users) although more than 90 percent have documents signed with the Reserve Banks to do it. Most of the largest users of daylight overdrafts, however, have sufficient unencumbered collateral pledged to the Reserve Banks to cover their average level of daylight overdrafts.

\section{The changes implemented in March 2009 have already helped to ease the} significantly stricter limitations faced by FBOs. The calculation of the deductible, which was the main concern for FBOs, has been aligned with U.S. chartered institutions for the highest-rated FBOs (these represent 10 percent of foreign participants and 40 percent of FBOs' use of intraday credit). FBOs will continue to be monitored at their cap level in real time, whereas only 5 percent of institutions are monitored in real time (for the others there is ex post control and corrective measures required in case of need). When there is real time monitoring of an institution, any outgoing Fedwire Funds transfer that exceeds available funds is rejected.

\section{The Board of Governors may consider further changes to increase the use of} collateralized intraday credit over the medium term and following appropriate cost benefit analysis. Although the new policy will relax some aspects of the net debit cap program, caps on total intraday credit will remain. As mentioned in the revised PSR Policy, "the Board may in the future consider the costs and benefits of moving further toward a fully collateralized structure."

\section{EFForts to Reduce Late-Day Settlement in Payment Systems AND MARKET INFRASTRUCTURES}

\section{The Fed is working on three other areas to help address late-in-the-day} payments and liquidity pressures in the payment systems. When in 2008 the Fed approved the revised PSR policy, there was an expectation that the financial industry would continue to review market clearing and settlement practices and pursue the elements of a so-

\footnotetext{
${ }^{14}$ The range of assets eligible to be pledged as collateral to the Federal Reserve, includes ABS, AAA collateralized debt obligations, commercial mortgage-backed securities, loans, and certain foreign currencydenominated assets. See http://www.frbdiscountwindow.org/discountmargins.cfm?hdrID=21\&dtlID=83.
} 
called "four-prong strategy" to address intraday liquidity, and operational and credit risks in the wholesale payment and settlement system. The three other efforts cover the potential development of a liquidity saving mechanism for Fedwire Funds, reducing the aggregate value of end-of-day settlement in CHIPS, and improvements in intraday liquidity usage for DTC..$^{15}$

\section{A. Liquidity Saving Mechanism in Fedwire Funds}

\section{The Fed Banks have been exploring with the industry the possibility of} developing a liquidity-saving mechanism for Fedwire Funds. Over the past decade, the trend in the new generation of RTGS payment systems, e.g., in Europe and Japan, has been to incorporate queuing and offsetting arrangements, which save a large amount of the liquidity needed to complete settlement while retaining the immediate finality of gross real time systems. Fedwire Funds is currently a traditional RTGS system, without any queuing mechanism or liquidity saving features.

\section{Introducing a liquidity-saving mechanism would economize on the amount of} intraday credit and collateral needed to settle a given value of transactions. It could also encourage the coordinated release of payments held in the liquidity queues of participants by reducing the total liquidity (and collateral in the new intraday credit policy to be implemented soon) used to fund those payments. In the current framework, where participants manage internal payment queues, there is no visibility of the incoming payments queued by their counterparties, which complicates intraday liquidity management. ${ }^{16}$

\section{The implementation of a liquidity-saving mechanism in Fedwire Funds would} need to be economically viable. Under the Monetary Control Act (MCA) of 1980, fees for the financial services provided by the Reserve Banks (which include the operation of Fedwire Funds and Securities) must be set, over the long run, to recover the actual costs incurred to provide the services, as well as costs the Reserve Banks would have incurred and imputed profits they would have expected to earn if they were private sector firms. These legal requirements are seen by the Fed and by the users as a powerful tool to promote efficiency and provide for equitable competition. The recent decline of volumes in Fedwire

\footnotetext{
${ }^{15}$ These initiatives have been a collaborative effort by the Federal Reserve and the industry, especially elaborated in the context of the Payment Risk Committee (PRC) and of the Wholesale Customer Advisory Group (WCAG). The PRC is sponsored by the Federal Reserve Bank of New York and works to identify and analyze issues of mutual interest related to risk in payments and settlement. The WCAG advises the Wholesale Product Office of the Federal Reserve Bank of New York, which is in charge of the management of Fedwire Funds and Securities. The composition of both PRC and WCAG consists of the largest institutions, domestic and foreign.
}

\footnotetext{
${ }^{16}$ In the context of the PRC and WCAG work, the development of a liquidity-saving mechanism was supported by most of the largest institutions, especially the foreign participants as efficiency gains of moving payments from individual institution queues to a centralized queue that would enable timely matching, offsetting of payments and increased transparency. Some institutions, however, expressed a different view, emphasizing that CHIPS already provides liquidity-saving features and that there is no interest in having also such an arrangement in Fedwire Funds.
} 
Funds (as in most payment and settlement systems in the U.S. and in industrialized countries) and the implications of policy actions could make full cost recovery more challenging.

\section{B. Reducing End-of-Day Settlement in CHIPS}

\section{The settlement model used by CHIPS is very robust and eliminates the} settlement risk associated with classical net deferred settlement systems. From a liquidity management perspective, the system is also very efficient as it minimizes the amount of funding in central bank money that is needed to complete the settlement of large values and volumes of underlying payments, thanks to its offsetting algorithm.

\section{The smooth functioning of the system and its ability to avoid trapping liquidity} until the end of the day is, however, dependent upon the behavior of its participants to:

(i) send on a given day payments in CHIPS that do not significantly differ from their average profile used by the central system to calculate their initial prefunding requirement; (ii) provide supplemental pay-in funding as needed during the day to avoid gridlocks and queuing payments until the end-of-day; and (iii) fulfill their end-of-day final prefunding to permit the settlement of the remaining payments.

\section{Until recently, the value of payments that remain pending until the end of the} day was significant. A few hundred payment messages were still queued after the cut-off of CHIPS and many were significant in value terms (ranging between US\$85 billion to US $\$ 100$ billion on average in 2007). The completion of payments in the queue after the cutoff of CHIPS is contingent on the participants in a negative closing position paying in additional funds, which averaged in aggregate between US\$50-60 billion.

\section{These pending payments have adverse consequences in terms of liquidity}

management. Since some large value payments are only settled and final at the end of the day, it prevents the re-use of the funds by the receiving banks earlier in the day, including the possibility for long banks in CHIPS to withdraw and re-use the liquidity for completing payments in Fedwire Funds. This represents an additional obstacle for settlement in Fedwire earlier in the day.

27. Two initiatives have helped reduce end-of-day pending payments. On the receiving side, CHIPS has experimented with increasing the cap on participants' current positions (which limits the maximum amount of liquidity that any participant can accumulate to twice its initial position before the 5:00 p.m. closure of the system) and releasing the cap constraint earlier in the day. In several steps, the cap was increased to 6 times the initial position) from twice the initial position and the cap constraint was released earlier, moving from 5:00 p.m. to 3:00 p.m. On the sending side, CHIPS has also encouraged its participants to provide voluntarily more supplemental funding within the day, without waiting for the end-of-day final funding. From April 2008 to September 2009, the amount of supplemental 


\section{Box 1. Overview of the CHIPS Settlement Model}

The settlement model implemented by CHIPS since 2001, though partly on a bilateral or multilateral net basis, allows for immediate finality of payments, thanks to a pre-funding arrangement in central bank money. This reflects the trend observed in many countries for the past decade, to combine the benefits of RTGS settlement to provide real time finality with the liquidity saving features of net settlement systems.

To facilitate the settlement process, CHIPS maintains an account at the Federal Reserve Bank of New York on behalf of its participants. Each CHIPS participant must prefund the account each day in the amount of an opening primary position requirement, which, once funded via Fedwire funds transfer to the CHIPS account, is used to settle payment orders throughout the day. The amount of the initial prefunding is calculated weekly by CHIPS based on the size and number of transactions by the participant and cannot be removed by participants during the day.

During the operating day, participants submit payment orders to a centralized queue maintained by CHIPS. Each payment is settled immediately if the transaction does not result in either a negative primary position for the sender or a position for the receiver that is greater than twice its initial primary position (half of the value and more than 90 percent of payments are settled on this gross basis). If a payment cannot be settled using the funds in the CHIPS account, an optimization algorithm attempts to match the payment order with other payments in the queue against which it can be bi- or multilaterally offset and released with finality at the time of release from the queue. Debits and credits to the current primary position are reflected only in CHIPS's records and are not recorded on the books of the Federal Reserve Bank of New York.

Payments remain in the queue until they can be settled by the funds in the participant's position, offset against another payment, or deleted by the participant. The sender can also intervene to release queued payments by transferring more funds from its Fedwire account to feed a CHIPS balance, called the supplemental position, that is separate from the primary position. Supplemental prefunding can be withdrawn by the participant from CHIPS, subject to the constraint that the amount withdrawn must be the lesser of their current supplemental position and the total supplemental prefunding paid-in by the participant. The sender can also earmark payments with "urgent" or "preferred" priorities to be released immediately from the queue by tying funds from the supplemental position to these payments ahead of time.

At 17:00 ET, CHIPS attempts to match, net, set off, and release as many of the remaining payment orders in the queue as possible without putting any participant in a negative position. A multilateral net position for the residual payments pending in the queue is provisionally added to each participant's current combined position (which is the aggregation of the participant's primary position and supplemental position) to calculate the final net position. Each participant with a negative final position has 30 minutes to transfer that amount, called final prefunding, to the CHIPS account through Fedwire. Once all of the final prefunding transfers have been received, CHIPS uses this liquidity to release and settle all remaining payment orders in the queue. CHIPS then transfers the remaining positive balances to the participants through Fedwire. If any participant fails to make its final prefunding payment (which happened only once since 2001), CHIPS attempts to settle as many payments as possible using the available funds in the system.

The CHIPS settlement model greatly minimizes the settlement risk at stake in traditional deferred net settlement systems, which are exposed to the settlement failure of participants in a debit position. A failure in these systems has the effect of deferring or impeding final settlement of all balances stemming from the system, and ultimately of unwinding the operations of the defaulter(s). This may lead to unexpected changes in positions of non defaulting participants, late in the day with associated liquidity pressures that may cause second round defaults and systemic risk propagation. 
funding was increased by more than eight times. These two initiatives have reduced significantly the volume and value of payments pending in the CHIPS queue at the end of the day (under US $\$ 20$ billion in September 2009, less than 1 1/2 percent of the total value settled daily) and also the amount of final funding (around US $\$ 12$ billion) required to release pending payments.

28. Further efforts in this area should be encouraged. One issue is the fact that supplemental funding during the day remains voluntary, and is not subject to a binding rule. The criticality of this may become obvious as clearing balances return to more normal levels.

\section{Risk Management}

29. The crisis illustrates the need for robust risk management. This includes:

(i) taking into account the consequences of the high concentration of settlement activities; (ii) maintaining up-to-date stress testing liquidity scenarios to review the adequacy of risk management controls and increase awareness of risks with participants; (iii) continuing ongoing actions aimed at strengthening operational resilience; (iv) ensuring adequate access to central bank liquidity; and (v) taking account of critical interdependencies.

\section{A. Concentration of Settlement}

30. The U.S. large-value payment systems exhibit a significant level of concentration of flows among a few key participants. In Fedwire Funds, whereas there are about 7,500 participants, the largest participant represented in 2008 on average around 20 percent of settled value, the top five participants represented 63 percent, and the top 10 participants represented 79 percent. In CHIPS, 64 percent of the value is settled by the top five participants. Concentration levels in both systems are comparable to those in most other major industrial countries. This concentration can be related to several factors, including concentration of the banking system and of the correspondent banking business. However, such concentration is a potential source of vulnerability. Even in Fedwire Funds and CHIPS, where settlement patterns expose participants to little or no credit risk, the unexpected unavailability of a major participant (because of an operational failure or due to an insolvency or liquidity problem) for an operating day would likely raise substantial liquidity pressures for the other participants.

\section{Similar concentration risks arise in the case of CLS Bank, which provides a} settlement system for foreign exchange transactions. The CLS system is designed to ensure a simultaneous exchange of both legs of an FX transaction in order to eliminate settlement risk. Its risk management framework relies inter alia on a settlement model backed by: (i) funding requirements in central bank money calculated on a multilateral net basis; and (ii) a set of position limits aimed at ensuring that the net values of the short positions of participants could not exceed their funding capacity and the capacity of CLS 
Bank to draw on liquidity facilities from liquidity providers. ${ }^{17}$ However, the level of concentration in settlements among settlement members is very high in the CLS system, due in part to some settlement members settling for third parties that represent very large positions. ${ }^{18}$

\section{Nonetheless, CLS Bank performed well during the crisis. Major dislocations were} avoided since the settlement member that represented Lehman Brothers did not exercise its right to rescind the transactions entered on behalf of Lehman Brothers and completed its settlement obligations on Lehman's behalf. Even when a settlement member acting on behalf of a third party did exercise its right to rescind the transactions, as in the case of Refco's failure, the CLS system continued to function. In part this reflects the fact that CLS Bank does not guarantee settlement as a CCP would do.

\section{CLS Bank and its members should take advantage of the current review to} consider providing more direct access to some of the largest third parties, to the extent consistent with possible legal limitations to direct membership. Direct access of large-scale or systemically important third parties (e.g., CCPs) is being discussed within the CLS community, and this step would reduce the counterparty risk borne by third parties on their intermediary settlement member.

\section{B. Stress Testing and Simulations}

\section{CLS Bank conducts a range of stress and back-testing scenarios to review the adequacy of its risk management procedures. The simulations include inter alia the}

\footnotetext{
${ }^{17}$ Pay-in requirements in the 17 currencies have to be completed by specified times, because of the time-zone differences which oblige CLS Bank to have a funding period compatible with the overlapping opening hours of the different RTGS systems. However, the settlement of the USD funding, which intervenes at a period of time where there are very few competing payments to complete clearly puts less pressure on banks' intraday liquidity management than the funding in European and especially in Asian currencies. Another source of liquidity pressure is the so-called CLS Pay-In Call, which is the first means of raising additional liquidity in the event that a settlement member fails to satisfy its funding requirements. "Pay-In Call for settlement" would be issued to settlement members that have unsettled payment instructions with the failing settlement member, in order to maximize the number and value of settled payment instructions for that date. Pay-In Calls could pose significant liquidity issues because they are unexpected. The multilateral aspect of funding has substantially decreased the amount of liquidity necessary to settle with finality underlying FX transactions. CLS Bank has provided a liquidity management tool for reducing further the settlement members' funding obligations. This tool is the In/Out swap program, which permits settlement members to enter into bilateral intra-day FX swap transactions to reduce their short positions in certain currencies and other settlement members' long positions in those same currencies. The "out" leg of this I/O swap being settled outside CLS, it re-introduces settlement risk. One solution to mitigate this risk would be to create an additional same-day settlement session, which would allow settling in CLS Bank the "out" leg of the I/O Swaps. However, this project, which has been discussed for some time, may in turn create more liquidity pressure for funding in certain currencies.
}

${ }^{18}$ The terms on which a member agrees to provide such services to third parties are governed through private arrangements that do not directly involve CLS Bank. The increase in the number of third parties in recent years has been one important avenue to broaden the system's penetration in the FX market (which is estimated to be around 55 percent of the value of total trades in April 2006 according to the CPSS report "Progress in Reducing Foreign Exchange Settlement Risk," May 2008). 
adequacy of haircuts and the failure of the settlement member with the single largest funding obligation in a single currency. In light of the crisis, CLS Bank is working on some more extreme scenarios, like the failure of all settlement members of a given currency to complete their funding and the simultaneous failure of the liquidity providers in the same currency. The enrichment of stress testing scenarios is welcome as it is useful to continuously adjust the risk control measures.

\section{CHIPS and its parent Clearing House are developing stress testing programs.} CHIPS, in particular, has instituted a program to ensure that participants understand the consequences of a failure of one or more banks to honor their closing positions and to encourage participants to develop liquidity contingency plans. The Clearing House is also running and sharing with its participants simulations of the inability of participants to fund their positions in CHIPS. These scenarios include simulations of the failure of one or more banks to pay all their funding of the day or their closing position requirements, and the results are presented to the CHIPS business committee.

\section{Operational Resilience}

36. The three payment systems operating in the U.S. have in place state of the art and highly resilient arrangements to mitigate operational risk. Fedwire, CHIPS and CLS Bank maintain very high levels of availability exceeding 99.9 percent, comprehensive business continuity plan (BCP) arrangements, capacity planning and apply best practices in terms of security requirements. CHIPS and CLS Bank have full synchronous mirroring of data between their two respective data centers, which allows for a quick recovery from the back-up site, in case of a disruption in the primary site, while Fedwire has multiple out-ofregion back-up data centers. $\mathrm{BCP}$ arrangements cover a wide range of threats, including pandemic ones. Alongside the implementation of the 2003 interagency paper on sound practices to strengthen the operational resilience of the U.S. financial system, issued in the post 9/11 context, additional measures have been undertaken to strengthen further the operational resilience of payment systems, including action by CHIPS to establish a new, remote data center in 2008 .

\section{Another important issue is to consider the occurrence of an operational problem} in the context of a stressed market situation. During the crisis, systems were able to process unexpected peak volumes without major problem. However, there is still the question of how market participants would react to a major operational problem, e.g. affecting a key participant in a payment system, occurring in a general context of serious concerns about credit and liquidity risks. Adequate preparation for such a scenario requires continuous initiatives to strengthen operational resilience of systems and their participants. Bank supervisors address these issues on an ongoing basis as part of the supervisory process. 


\section{Access of Systemically Important Infrastructures to Central Bank Services}

38. The Administration's proposed legislation (Title VIII) would also entitle the Fed to open an account and provide access to discount window credit for financial market utilities designated as systemically important. The current framework limits account access to state member banks, other depository institutions, and certain other institutions specified by statute. Therefore, while bank-chartered infrastructures may maintain an account with the Fed, other non-bank financial market infrastructures cannot have accounts. For instance, the Fixed Income Clearing Corporation (FICC), which is the central counterparty for government bonds, is not allowed to open an account either in Fedwire Funds or in Fedwire Securities. This leads to a greater reliance on commercial banks by financial market infrastructures to perform settlement. ${ }^{19}$ Allowing systematically important market infrastructures to settle in central bank money would limit settlement risk. In addition, financial market infrastructures may face extreme stress scenarios for which an adequate access to central bank credit (on terms and conditions to be decided by the Board) would be an additional buffer to mitigate systemic risk. ${ }^{20}$

\section{Measures which would facilitate settlement in central bank money for} systemically important infrastructures and access to credit are recommended. Giving non-bank financial market infrastructures access to a central bank account and liquidity under terms and conditions established by the Federal Reserve Board would need to be coupled with a strong oversight framework and full compliance of the systems with U.S. regulatory requirements regarding risk management and, as appropriate, consistent with international standards.

\section{E. Interdependencies}

40. The U.S. payment systems are highly interconnected globally. This reflects the participation of a large number of both U.S. and foreign internationally-active institutions, as well as the critical role that the CHIPS and (especially) the CLS systems play in settling cross border payments. Moreover, U.S. payment systems represent the worldwide end of day, which means that a disruption there could have important spillover effects at the following day opening of systems in Asia and Europe.

\section{Given the importance of these interdependencies, the U.S. authorities should} continue on-going initiatives with a view to carry out a comprehensive risk mapping exercise. It is important to take into account of all types of interdependencies within

\footnotetext{
${ }^{19}$ For more details, see the assessment of FICC against CPSS/IOSCO Recommendations for Securities Settlement System (SSSs).

${ }^{20}$ Examples of such risk include difficulties in timely liquidation or obtaining liquidity against collateral because of a market dislocation, or the difficulty for a CCP to find depository banks to hold safely margins collected from its participants.
} 
settlement systems and across systems (e.g., funding linkages between CHIPS and Fedwire Funds). 